\title{
Effect of male vocalizations on the nest-occupation response of female budgerigars to oestrogen and prolactin
}

\author{
Elizabeth Steel, Susan Gosney and R. A. Hinde \\ M.R.C. Unit on the Development and Integration of Behaviour, \\ Madingley, Cambridge CB3 $8 A A, U . K$.
}

In the canary, the nest-building response of ovariectomized females to exogenous oestrogen is affected both by the length of the photoperiod (Steel \& Hinde, 1972) and by male vocalizations (Hinde \& Steel, 1976). Gosney \& Hinde (1975) showed a similar effect of photoperiod on an analagous behaviour in the budgerigar; oestrogen-treated ovariectomized birds entered the nest-box sooner and spent longer periods within if kept in a long-day than in a short-day photoperiod. In view of the essential role of male vocalizations on reproductive development in the female budgerigar (review by Brockway, 1969) the present paper investigates the effect of male vocalizations on hormoneinduced nest-box occupation by ovariectomized female budgerigars.

The finding of Gosney \& Hinde (1976) that intact females reach a greater degree of reproductive development if exposed to male song during the first half of a 14-h day than during the second half suggests that the sensitivity of the female to male song varies diurnally. The presence of a similar diurnal effect of song on the response to oestrogen is also investigated.

Naturally breeding females first enter the nest 8-9 days before the first egg is laid; just before laying about $60 \%$ of time is spent inside, rising to about $90 \%$ during incubation. Hutchison (1971) found that oestrogen alone would induce naive ovariectomized females to enter the nest-box. With increasing dose more birds entered and with slightly shorter latencies; $100 \mu \mathrm{g}$ thrice weekly caused $66 \%$ of females to enter within 15 days (median latency 4 days). A combination of oestrogen and prolactin caused all females to enter the nest-box and the time spent inside was comparable to that passed by intact naturally breeding birds. The hormone dosages used here are based on Hutchison's data.

The basic procedure for the 4 experiments was similar: details specific to each experiment are given in Table 1. Birds ovariectomized 1-3 months previously were subjected to laparotomy 1 week before experiment and any with residual ovarian tissue were rejected. At the end of each experiment any bird with ovarian tissue weighing $>0.1 \%$ body weight or with a follicle $>1 \mathrm{~mm}$ diameter was rejected and does not appear in the analysis. For a week before the experiment birds were housed singly in an 11L:13D photoperiod in cages with a communicating nest box, the entrance of which was blocked. On Day 0 the experimental conditions (14L:10D photoperiod and sound) were introduced, the nest boxes opened and the first injection given. Injections were repeated thrice weekly. Tape recordings of budgerigars and canaries in all-male groups were made on 10-min continuously playing loops. Latency to first nest-box entry was recorded by means of a piece of smoked paper (inspected daily) placed in the base of the nest box; additional data on numbers of birds entering during watches are also given. To estimate the amount of time spent in the nest box groups of birds were watched and recorded as in or out of the nest box at $30 \mathrm{sec}$ intervals. Two-hour watching periods started $2 \frac{1}{2}$ or $6 \frac{1}{2} \mathrm{~h}$ after dawn. The results are presented as the percentage of total possible observations in which the bird was in the nest.

Mann-Whitney U tests (M.W.U.) were used to assess differences in latency to enter and the percentage of time in the nest box. The Fisher Exact Probability (F.E.) test was used to assess the number of birds entering or not entering. All probabilities are one-tailed.

Experiments $1($ a) ( 7 days duration) and $I(b)$ (14 days duration). The effect of male vocalization on the latency of oestrogen-induced nest-box entry by the female was recorded. Not all birds entered and those that did showed a considerable range of latencies. In both groups the median latency to enter was only slightly less when song was played and in neither was the difference significant. 
Experiment 2. The more effective combination of oestrogen and prolactin was used, and attention was focused on time in the nest box during watches rather than latency to enter. In the birds receiving song the number entering rose from 3 (Day 1) to 8 (Day 8); no more than 3 birds entered on any one day in the no-song group. All birds entered during at least one watch in the song group, but only $4 / 7$ did so in the no-song group. During the watches significantly more birds receiving song entered the nest box on Days 3, 7 , and $8(P<0.05$, F.E. $)$.

From Day 3 onward the median percentage of time spent in the nest box during watches was greater for the song group; the difference was significant on Days 3,4 and 7 ( $P<0.05$, M.W.U.). The median time in the nest increased from $0 \%$ on Days 1 and 2 to $40 \%$ on Days 7 and 9 . The median scores of the no-song group were $0 \%$ on all watches. Over all watches combined the medians were $22 \%$ (song group) and $0.3 \%$ (no-song group) $(P<0.05$, M.W.U.).

Table 1. Details of hormone treatments of, exposure to vocalizations of and duration of observations on female budgerigars

\begin{tabular}{|c|c|c|c|c|c|c|c|c|}
\hline \multirow[b]{3}{*}{ Exp. } & \multirow{2}{*}{\multicolumn{2}{|c|}{ Hormone treatment }} & \multirow[b]{3}{*}{$\begin{array}{l}\text { No. of } \\
\text { birds }\end{array}$} & \multirow[b]{3}{*}{$\begin{array}{l}\text { Type of } \\
\text { song }\end{array}$} & \multirow[b]{3}{*}{$\begin{array}{c}\text { Time of exposure } \\
\text { to song }\end{array}$} & \multicolumn{2}{|c|}{ Recording } & \multirow[b]{3}{*}{$\begin{array}{l}\text { Autopsy } \\
\text { (Day) }\end{array}$} \\
\hline & & & & & & \multirow{2}{*}{$\begin{array}{c}\text { Latency } \\
\text { to } \\
\text { nest- } \\
\text { box } \\
\text { entry }\end{array}$} & \multirow[b]{2}{*}{$\begin{array}{l}\text { Time spent } \\
\text { in nest-box }\end{array}$} & \\
\hline & $\begin{array}{l}\text { benzoate } \\
(\mu \mathrm{g})\end{array}$ & $\begin{array}{l}\text { Prolactin } \\
\text { (i.u.) }\end{array}$ & & & & & & \\
\hline $1(a)$ & 100 & 一 & $\begin{array}{l}7 \\
8\end{array}$ & $\begin{array}{l}\text { Budgerigar } \\
\text { None }\end{array}$ & Alternate hours & Yes & No & 7 \\
\hline $1(b)$ & 100 & - & $\begin{array}{l}7 \\
6\end{array}$ & $\begin{array}{l}\text { Budgerigar } \\
\text { None }\end{array}$ & $\begin{array}{l}\text { during 14-h } \\
\text { light period }\end{array}$ & Yes & No & 14 \\
\hline 2 & 100 & 100 & $\begin{array}{l}8 \\
7\end{array}$ & $\begin{array}{l}\text { Budgerigar } \\
\text { None }\end{array}$ & $\begin{array}{l}\text { Alternate hours } \\
\text { during 14-h light } \\
\text { period }\end{array}$ & No & $\begin{array}{l}\text { 2-h watches } \\
\text { Days } 1,2,3,4 \text {, } \\
7,8 \text { and } 9\end{array}$ & 10 \\
\hline 3(a) & 100 & 50 & $\begin{array}{r}10 \\
9\end{array}$ & $\begin{array}{l}\text { Budgerigar } \\
\text { Canary }\end{array}$ & Alternate hours & Yes & $\begin{array}{l}\text { 2-h watches } \\
\text { Days } 1,2,3,4 \\
\quad \text { and } 7\end{array}$ & 8 \\
\hline 3(b) & 100 & 100 & $\begin{array}{l}8 \\
8\end{array}$ & $\begin{array}{l}\text { Budgerigar } \\
\text { Canary }\end{array}$ & $\begin{array}{l}\text { during } 14-h \\
\text { light period }\end{array}$ & Yes & $\begin{array}{l}\text { 2-h watches } \\
\text { Days } 1,2,3,4 \text {, } \\
7,10 \text { and } 11\end{array}$ & 12 \\
\hline 4 & 100 & 100 & $\begin{array}{r}9 \\
10\end{array}$ & $\begin{array}{l}\text { Budgerigar } \\
\text { Budgerigar }\end{array}$ & $\begin{array}{l}\text { First } 7 \mathrm{~h} \text { of } 14-\mathrm{h} \text { light } \\
\text { period } \\
\text { Second } 7 \mathrm{~h} \text { of } 14-\mathrm{h} \\
\text { light period }\end{array}$ & Yes & $\begin{array}{l}\text { 1-h watches } \\
\text { twice daily } \\
\text { Days } 1,2,4 \\
\text { and } 7\end{array}$ & 8 \\
\hline
\end{tabular}

Experiments 3(a) and 3(b). The procedure was the same as in Exp. 2, except that a group exposed to canary song (an unrelated species) was substituted for the no-song control. Both latency to enter and time spent in the nest box were assessed.

In Exp. 3(a) there were no significant differences in latency to enter the nest box between the two conditions although $8 / 10$ birds in the budgerigar song group had entered by Day 1 compared with $4 / 9$ in the canary song group. The number of birds entering during watches rose during the 7 days of the experiment from $4 / 9$ to $9 / 9$ (canary song) and from $7 / 10$ to $9 / 10$ (budgerigar song); in no single watch were these differences significant.

On Days 1-4 but not on Day 7 the median percentage of time spent in the nest box was greater for the budgerigar song group than for the canary song group; these differences were significant on Day $2(P<0.001$, M.W.U.) and Days 3 and $4(P<0.05$, M.W.U.). Over all watches the budgerigar song group spent a median of $42 \%$ of time in the nest while the canary song group spent only $19 \%$ $(P<0.05$, M.W.U.). 
In Exp. 3(b) all birds entered by Day 1 except for one (canary song) which first entered on Day 6. Slightly more birds entered during watches in the budgerigar song group but the differences were not significant.

In 6 out of the 7 watches the budgerigar song group spent a greater median percentage of time in the nest; the differences were significant on Day $1(P<0.01$, M.W.U. $)$ and Days 7 and $10(P<0.05$, M.W.U.). Over all watches the budgerigar song group spent a median of $83 \%$ of time in the nest while the canary group spent $56 \%(P<0.01$, M.W.U. $)$.

Experiment 4. The effect of budgerigar song played during the first (early) or the second (late) $7 \mathrm{~h}$ of a 14-h day was assessed as the time spent in the nest by oestrogen plus prolactin-treated females. The groups were watched during the morning and afternoon on Days 1, 2, 4 and 7.

All birds had entered the nest box by Day 1 . On the 4 watch days all 9 birds in the early group entered during watches; not every bird in the late group entered during every watch. Wilcoxonmatched pairs tests, carried out on each group for each day, showed that there was no consistent tendency to spend more time in the nest at one of these times of day than the other, and consequently no tendency to spend more time in the nest while the recording of male budgerigar song was actually playing.

The data from morning and afternoon watches were thus combined for each day. The early group spent more time in the nest on all 4 days, significantly so on Days 2,4 and $7(P<0 \cdot 01$, M.W.U.). Over all watches the early group spent a median of $77 \%$ of time in the nest while the late group spent only $24 \%(P<0.01$, M.W.U. $)$.

Male song in the budgerigar, besides stimulating the hypothalamus-pituitary-gonad axis, can also modify the behavioural response to exogenous oestrogen and prolactin in the ovariectomized bird. It has at most a small influence on latency to enter the nest box with either oestrogen alone or in combination with prolactin. The effect on time spent in the nest (with oestrogen + prolactin treatment) is greater with conspecific song than with canary song and is affected by the time of day at which the song is heard. A greater sensitivity to song in the early part of the day agrees with the previous finding that reproductive development is accelerated more by song at this time of day.

The prolactin (Ovine, NIH-P-S12) was supplied by the National Institutes of Health.

\section{References}

BrockWAY, B.F. (1969) Roles of budgerigar vocalizations in the integration of breeding behaviour. In Bird Vocalizations, pp. 131-158. Ed. R. A. Hinde. Cambridge University Press.

GosNey, S. \& Hinde, R.A. (1975) An oestrogenmediated effect of photoperiod on the reproductive behaviour of the budgerigar. J. Reprod. Fert. 45, 547-548.

GosNey, S. \& Hinde, R.A. (1976) Changes in the sensitivity of female budgerigars to male vocalizations. J. Zool., Lond. 179, 407-410.
Hinde, R.A. \& Steel, E. (1976) The effect of male song on an oestrogen-dependent behaviour pattern in the female canary (Serinus canarius). Horm. \& Behav. 7, (in press).

HuTCHISON, R.E. (1971) The integration of reproductive behaviour in female budgerigars. Ph.D. thesis, University of Cambridge.

STEeL, E. \& HINDE, R.A. (1972) Influence of photoperiod on oestrogenic induction of nest-building in canaries. J. Endocr. 55, 265-278.

Received 20 May 1976 